\title{
PENINGKATAN PENGETAHUAN SISWA DALAM MEMILIH JAJANAN MAKANAN DI LEMBAGA PENDIDIKAN PERMATA JANNATI KOTA BANJARMASIN \\ TAHUN 2016
}

\author{
Achmad Rizal dan Agus Jalpi \\ Fakultas Kesehatan Masyarakat, Universitas Islam Kalimantan MAB Banjarmasin \\ Email: achmadrizal.fkmuniska@gmail.com
}

\begin{abstract}
The quality of human resources improve is considered a key factor it takes to execute national development. Food hawker school is problems that need to be an attention for the community, especially the people old, educator, and the school management. Food and hawker school principal is at risk to biologist or chemically dirt. The results of supervision food hawker school children by BPOM of Indonesia in 2010 shows that of 2945 samples to be taken in 26 the capital provinces in Indonesia 48,35\% did not qualified. Snack habits at the school very useful if take-out is meeting requirements health, so that it could complete or add needs child nutrition these extension aims to tense knowledge students to hawker of healthy food, a participant in these extension were elementary school students in research institutes Permata Jannati Banjarmasin.
\end{abstract}

Keywords: School Children, Snack Foods,Habits, Health Food,Knowledge.

\section{PENDAHULUAN}

Kualitas sumber daya manusia (SDM) merupakan faktor utama yang diperlukan untuk melaksanakan pembangunan nasional. Faktor gizi memegang peranan penting dalam mencapai SDM berkualitas (Depkes RI, 2005).Gizi yang baik akan menghasilkan SDM yang berkualitas yaitu sehat, cerdas dan memiliki fisik yang tangguh serta produktif. Perbaikan gizi diperlukan pada seluruh siklus kehidupan, mulai sejak masa kehamilan, bayi dan anak balita, pra sekolah, anak SD dan MI, remaja dan dewasa sampai usia lanjut . (Dwi, 2005).

Upaya peningkatan status gizi untuk pembangunan sumber daya manusia yang berkualitas pada hakekatnya harus dimulai sedini mungkin, salah satunya anak usia sekolah. Anak sekolah dasar merupakan sasaran strategis dalam perbaikan gizi masyarakat (Calderon, 2002).

Makanan bergizi bisa diperoleh dari makanan utama dan makanan jajanan.Jajanan merupakan salah satu makanan yang dikenal dan umum dimasyarakat, terutama anak usia sekolah. Hampir disetiap sekolah pasti 
dijumpai para pedagang makanan jajanan. Hal ini mendorong timbulnya kebiasaan mengonsumsi makanan jajanan pada anak sekolah, terutama pada jeda jam istirahat sekolah (Umiyarni, 2010)

Makanan jajanan adalah makanan yang dibeli dalam bentuk siap dikonsumsi.Makanan jajanan banyak disukai anak-anak karna harganya relatif murah,mudah diperoleh ,tampilannya menarik dan bervariasi. Makanan jajanan adalah jenis makanan yang dijual dikaki lima,pinggir jalan,stasiun,pasar , ditempat pemukiman serta lokasi yang sejenis (Winarno, 1997).

Selain makanan utama yang dihidangkan di rumah, makanan jajanan juga dapat berfungsi menambah pemasukan energi dan zat gizi lain seperti protein ke dalam tubuh. Hal ini sesuai dengan pernyataan Winarno (1998).Kebiasaan mengkonsumsi makanan jajanan mempunyai keuntungan ganda yaitu selain untuk tambahan zat gizi juga berguna untuk mengisi kekosongan lambung.Hidayat (1997).

Kebiasaan jajan disekolah sangat bermanfaat jika makanan yang dibeli itu sudah memenuhi syarat-syarat kesehatan,sehingga dapat melengkapi atau menambah kebutuhan gizi anak. Disamping itu juga untuk mengisi kekosongan lambung,Karena setiap 3-4 jam sesudah makan,lambung mulai kosong. Akhirnya apabila tidak diberi jajan ,si anak tidak dapat memusatkan kembali pikirannya kepada pelajaran yang diberikan oleh guru kelasnya. Jajan juga dapat digunakan untuk mendidik anak dalam memilih jajan menurut 4 sehat 5 sempurna (Yusuf dkk, 2008)

Kebiasaan mengkonsumsi makanan jajanan sehat masih belum banyak dimiliki oleh siswa, terutama siswa Sekolah Dasar (SD). Penelitian yang telah dilakukan oleh Irawati dkk (1998) menunjukkan bahwa siswa Sekolah Dasar masih belum dapat memilih makanan jajanan yang sehat dan bersih, hal tersebut tercermin dari makanan jajanan yang dikonsumsi siswa SD di sekolah masih banyak yang mengandung pewarna sintetik, logam berat, bakteri patogen dan lain-lain .

Makanan jajanan sekolah merupakan masalah yang perlu menjadi perhatian masyarakat, khususnya orang tua, pendidik, dan pengelola sekolah.Makanan dan jajanan sekolah sangat beresiko terhadap cemaran 
biologis atau kimiawi yang banyak menganggu kesehatan, baik jangka pendek maupun jangka panjang (Februhartanty dan Iswaranti, 2004).

Hasil pengawasan pangan jajanan anak sekolah oleh BPOM RI tahun 2010 menunjukkan bahwa dari 2945 sampel yang diambil di 26 ibu kota Propinsi di Indonesia $48,35 \%$ tidak memenuhi syarat. Penelitian yang dilakukan BPOM dengan IPB (2012) di 4500 SD di 18 Propinsi menunjukkan bahwa masih banyak bahan tambahan berbahaya dan mikroba pada pangan jajanan anak sekolah sebanyak 12,7\% sampel pangan utama mengandung formalin seperti nasi uduk, nasi goreng, lontong, bakso, mie basah. Sebanyak 9,7\% mengandung boraks.

Berdasarkan hasil penelitian Badan Pengawas Obat Makanan (BPOM) Kalsel (2013) diketahui bahwa jajanan anak-anak di kalimantan selatan ditemui cemaran mikroba atau logam berat dan zat berbahaya lainnya diatas ambang batas ditetapkan. Dinkes bersama dengan BPOM mendapatkan fakta sangat memprihatinkan yaitu $28 \%$ dari jajanan anak-anak kini tercemar mikroba dan zat berbahaya lainnya cukup tinggi Zat berbahaya tersebut antara lain pewarnaan ada yang menggunakan warna non makanan, adanya zat pemanis berlebihan, pengawet dan lainnya. Zat berbahaya tersebut membuat anak-anak tidak bisa tumbuh dengan baik, pemanis yang banyak ditemukan pada minuman juga tidak ada kalorinya.Sehingga energi untuk belajar menjadi sangat kurang. Makanan dengan bahan pengawet juga membuat daya tahan tubuh anak berkurang sehingga akan mudah terserang berbagai penyakit. Selain itu mengingat ditemukannya banyak sekali jajanan anak sekolah di Banjarmasin yang mengandung bahan berbahaya seperti formalin, rodamine, boraks, atau natrium. Berdasarkan uji Laboratorium terhadap 198 sampel jajanan makanan yang sering diperjual belikan tersebut,94 sampel dinilai tidak memenuhi standar yang disyaratkan bagi kesehatan.(antarakalsel,2013).

Selama ini masih banyak jajanan sekolah yang kurang terjamin kesehatannya dan berpotensi menyebabkan keracunan.Dengan banyaknya makanan yang mengandung bahan kimia berbahaya di pasaran, kantin-kantin sekolah, dan penjaja makanan di sekitar sekolah merupakan agen penting yang bisa membuat siswa mengkonsumsi makanan tidak 
sehat.Sebuah survei di 220 Kabupaten dan kota di Indonesia menemukan hanya $16 \%$ sekolah yang memenuhi syarat pengelolaan kantin sehat (Suci, 2009).

Makanan jajanan yang dijual oleh pedagang kaki lima menurut FAO didefinisikan sebagai makanan atau minuman yang dipersiapkan dan atau dijual oleh pedagang kaki lima di jalanan dan ditempat keramaian umum lain yang langsung dimakan tanpa pengolahan atau persiapan lebih lanjut. Makanan jajanan anak sekolah yang diproduksi secara tradisional dalam bentuk industri rumah tangga memang diragukan keamanannya.Meskipun jajanan yang diproduksi industri makanan tersebut berteknologi tinggi, belum tentu terjamin keamanannya. Oleh karena itu, kemanan pangan jajanan merupakan salah satu masalah kesehatan masyarakat yang perlu mendapatkan perhatian serius, konsisten dan disikapi bersama (Februhartanty dan Iswaranti, 2004).

Dampak dan resiko mengkonsumsi jajanan makanan siap saji menurut World Health Organization (WHO) dan Food and Agricultural Organization (FAO) menyatakan bahwa ancaman potensial dari residu bahan makanan terhadap kesehatan manusia dibagi dalam 3 katagori yaitu aspek toksikologis, katagori residu bahan makanan yang dapat bersifat racun terhadap organ-organ tubuh, aspek mikrobiologis, mikroba dalam bahan makanan yang dapat mengganggu keseimbangan mikroba dalam saluran pencernaan, aspek imunopatologis, keberadaan residu yang dapat menurunkan kekebalan tubuh dampak terhadap kesehatan anak menyebabkan sesak napas, gatal-gatal, kerusakan otak kelainan hati dan gangguan syaraf (Maya, 2010).

\section{KHALAYAK SASARAN}

Sasaran dalam kegiatan pengabdian ini adalah siswa SD di Lembaga Pendidikan Permata Jannati, dimana daerah tersebut adalah wilayahditemukan banyak pedagang yang bejualahan disekitar sekolah beberapa jenis makanan yang dijual yaitu aneka gorengan, bakso, kue- kue, aneka es dll.Tingkat pendidikan siswaSD di Lembaga Pendidikan Permata Jannati yang masih rendah mengakibatkan pengetahuan tentang jajanan makanan.Pengetahuan menjadi sangat penting dalam menentukan sikap dan perilaku siswa dalam melakukan 
memilih jajanan makanan yang bersih dan sehat.

\section{METODE}

Peningkatan pengetahuan siswa tentangkebersihan jajanan makanan dilakukan dengan cara pemberian informasi (edukasi) berupa penyuluhan kesehatan tentang jajanan makanan yang sehat dan bergizi.

\section{HASIL DAN PEMBAHASAN}

Salah satu sekolah di Kota Banjarmasin yaitu di Lembaga Pendidikan Permata Jannati yang terletak diwilayah Banjarmasin Utara, Berdasarkan studi awal ditemukan banyak pedagang yang bejualahan disekitar sekolah beberapa jenis makanan yang dijual yaitu aneka gorengan, bakso, kue- kue, aneka es dll.Jenis makanan jajanan yang dikonsumsi anak sekolah dapat beresiko terhadap kesehatan seperti diare, gatalgatal, mengganggu fungsi otak, gangguan hati, pencernaan untuk itu pentingnya memilih jajanan bagi anak sekolah dipengaruhi untuk pengetahuan tentang jajanan sehat.

Berikut susunan acara pelaksanaan pengabdian Jenis Kegiatan : Penyuluhan

$\begin{array}{lll}\text { Tempat } & : \text { Aula/ Ruang Kelas SDIT } \\ & \text { Permata Jannati } \\ \text { Waktu }: \text { Pkl 10.00, } & \text { Selasa } \\ & \text { Tanggal } 1 \text { November } \\ & 2016 \\ \text { Peserta } \quad: & \text { Siswa Kelas } 4 \text { SDIT } \\ & \text { Permata Jannati }\end{array}$

Tabel 1. Uraian Kegiatan Penyuluhan

\begin{tabular}{|c|c|c|}
\hline Waktu & $\begin{array}{l}\text { Jenis } \\
\text { Kegiatan }\end{array}$ & $\begin{array}{l}\text { Penanggung } \\
\text { Jawab }\end{array}$ \\
\hline $\begin{array}{l}\text { Pkl. } \\
09.00- \\
09.15\end{array}$ & Persiapan & $\begin{array}{l}\text { Tim } \\
\text { Pelaksana }\end{array}$ \\
\hline $\begin{array}{l}\text { Pkl. } \\
10.00- \\
10.15\end{array}$ & Pembukaan & $\begin{array}{l}\text { Pembawa } \\
\text { Acara }\end{array}$ \\
\hline $\begin{array}{l}\text { Pkl. } \\
10.15- \\
11.00\end{array}$ & $\begin{array}{l}\text { Pemberian } \\
\text { Materi } \\
\text { - Pengertian } \\
\text { Jajanan } \\
\text { Sehat dan } \\
\text { tidak sehat } \\
\text { - Dampak } \\
\text { Jajanan } \\
\text { yang tdk } \\
\text { sehat }\end{array}$ & $\begin{array}{l}\text { Pemateri } \\
\text { (Achmad } \\
\text { Rizal, SKM., } \\
\text { M.Kes) }\end{array}$ \\
\hline $\begin{array}{l}\text { Pkl. } \\
11.00- \\
11.30\end{array}$ & $\begin{array}{l}\text { Pemberian } \\
\text { Materi } \\
\text { - Memilih } \\
\text { Jajanan } \\
\text { sehat } \\
\end{array}$ & $\begin{array}{l}\text { Pemateri } \\
\text { (Agus Jalpi, } \\
\text { SKM., } \\
\text { M.Kes) }\end{array}$ \\
\hline $\begin{array}{l}\text { Pkl. } \\
11.30- \\
11.45\end{array}$ & $\begin{array}{l}\text { Diskusi Tanya } \\
\text { jawab }\end{array}$ & $\begin{array}{l}\text { Pembawa } \\
\text { Acara }\end{array}$ \\
\hline $\begin{array}{l}\text { Pkl. } \\
12.00\end{array}$ & Penutup & $\begin{array}{l}\text { Pembawa } \\
\text { Acara }\end{array}$ \\
\hline
\end{tabular}




\section{FOTO KEGIATAN}

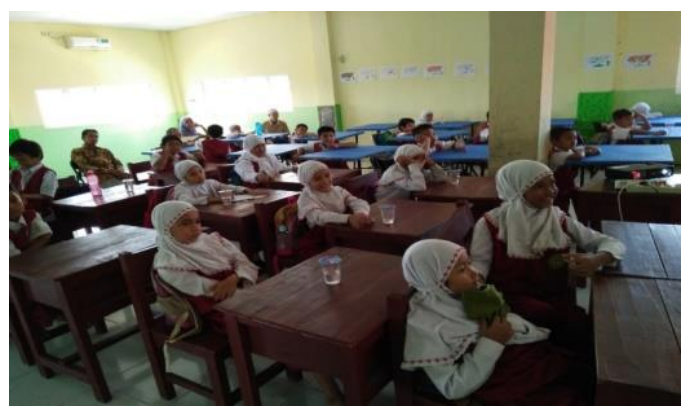

Kegiatan penyuluhan diawali dengan pemberian informasi dan kemudian dilanjutkan dengan Tanya jawab atau diskusi dengan siswa.

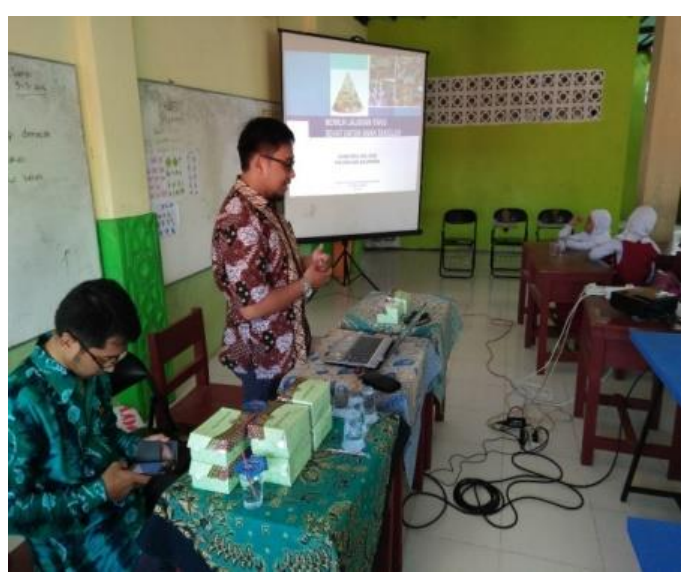

Kegiatan ini dilaksanakan selama 1 hari SDIT Permata Jannati Sultan Adam Banjarmasin.

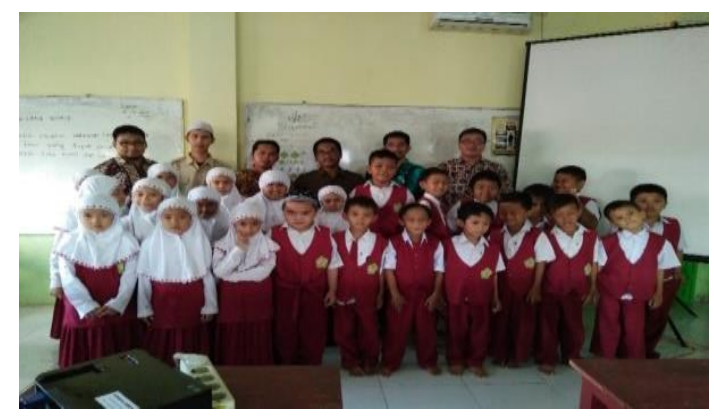

Kegiatan penyuluhan ini dilakukan dengan cara mengumpulkan siswa dengan koordinasi dewan guru yang diundang.

\section{KESIMPULAN}

Berdasarkan ManfaatPengabdian yang dilaksanakan dapat diharapkan mampu memberikan Bagi pihak sekolah yaitu sebagai bahan masukan dalam melakukan intervensi dan pemantauan terhadap penjual makanan jajanan di lingkungan sekolah, bagi Siswa yaitu sebagai informasi akan pengetahuan anak sekolah dengan kebiasaan memilih jajanan makanan, sebagai pengalaman dalam mengaplikasikan teori dan ilmu pengetahuan dan diharapkan menjadi masukan dan bahan perhatian bagi ilmu kesehatan masyarakat dalam hal peningkatan pengetahuan dengan kebiasaan memilih jajanan makanan.

\section{DAFTAR PUSTAKA}

Amelia, Kindi. 2013. Hubungan Pengetahuan Makanan dengan Frekuensi Konsumsi Makanan Pada Anak Sekolah Dasar Pembangunan Laboratorium Universitas Negeri Padang.Fakultas Tehnik Universitas Negeri padanghttp://ejournal.unp.ac.id/in dex.php/jhet/article/download/890 1744 (diakses pada tanggal $28 \mathrm{Mei}$ 2016) 
Arikunto, Suharsimi. 2009. Prosedur Penelitian Suatu Pendekatan Praktek. Jakarta: Rineka Cipta.

Dewanti, Tri Keamanan Makanan Jajanan. FTP-Universitas Brawijaya http://tridewanti.lecture .ub.ac.id

Erfandi, 2009.Pengetahuan dan faktorfaktor yang Mempengaruhihttp://forbetterheal th.wordpress.com/2009/04/19/pen getahuan-dan-faktor-faktor-yangmempengaruhi

Notoatmodjo, Soekidjo. 2010. Metodologi Penelitian Kesehatan. Jakarta: Rineka Cipta.

Priyanto, Dwi. 2008. Mandiri Belajar SPSS. Yogyakarta: Mediakom

Putri, Evie Widya surya. 2010. Karakteristik

Anak
SDhttp://Evie4210.blogspot.com/ 2010/05/faktor-yang-dapat menurunkan-moral-di.html?m=1 Purtiantini.2010. Hubungan Pengetahuan dan Sikap Mengenai PemilihanMakanan Jajanan Dengan Perilaku Anak Memilih Makanan di SDITMuhammadiyah Al Kautsar Gumpang Kartasura.Skripsi yang tidakditerbitkan. Surakarta: Prodi S-1 Ilmu Gizi Universitas MuhammadiahSurakarta.

Rusendy, Ria 2012. Pengertian Makanan Jajanan http://riarusendy89.blogspot.com/ 2012/12/Pengertian-makanan jajanan.html?m=1(diakses pada tanggal 28 Mei 2016) 